\title{
Self-Efficacy and Academic Anxiety of College Students
}

\author{
Isti Yuni Purwanti* \\ Guidance and Counseling \\ Universitas Negeri Yogyakarta \\ Yogyakarta, Indonesia \\ istiyp@uny.ac.id*
}

\author{
Muh Nur Wangid \\ Guidance and Counseling \\ Universitas Negeri Yogyakarta \\ Yogyakarta, Indonesia \\ m_nurwangid@uny.ac.id
}

\author{
Siti Aminah \\ Guidance and Counseling \\ Universitas Negeri Yogyakarta \\ Yogyakarta, Indonesia \\ sitiaminah@uny.ac.id
}

\begin{abstract}
The aim of this study is to describe the contribution of self-efficacy to the academic anxiety among the students of UNY (Universitas Negeri Yogyakarta). This correlational study used the descriptive-quantitative approach and the technique in collecting the data was through the questionnaires of self-efficacy and academic anxiety. All UNY students consisting of 7 faculties and 1 graduate program were involved as the population of this study. The sampling technique used krejcie tables with efficacy level of $90 \%$. The results of the Pearson Correlation model analysis test showed a correlation value of $\mathbf{- 0 . 6 7 4}$ with the opposite direction of the two variables in which the higher the academic self-efficacy, the lower the academic anxiety. The results of the correlation test based upon the exact and nonexact science showed results of $21.4 \%$ and $29.6 \%$, respectively. Meanwhile, the results of the correlation test by sex showed that male had a correlation of $11.4 \%$ and female had $28.6 \%$. Furthermore, the correlation test results by the class of 2016, 2017 and 2018 showed the value of $27.1 \%, 21.7 \%$ and $18.4 \%$ respectively. Furthermore, the results of the simple linear regression analysis of $\mathrm{R}$-square test obtained 0.281 indicating that self-efficacy brought an effect on the decrease of academic anxiety by $28.1 \%$, while $\mathbf{7 1 . 9 \%}$ was determined by other factors or other independent variables not used in this study.
\end{abstract}

Keywords-self-efficacy, academic anxiety, college students

\section{INTRODUCTION}

It has been found in a previous study on academic anxiety profile of UNY students in 2018 that the academic anxiety experienced by students was related to a number of factors, some of which that have been revealed in previous studies were the effects of academic anxiety based on the academic self-efficacy of students. This then comes to be a very interesting topic for further research to figure out of its contribution.

The study of Arnaiz Castro and Perez Luzardo's [1] supported this finding that the higher level of student academic anxiety could lead to the lower level of academic self-efficacy. While the study mentioned above was carried out for the secondary education level, this recent study attempted to be carried out on the college students and it was also supported from the results of previous studies on the academic anxiety among UNY students with an expectation that it can provide a better understand towards the contribution of academic self-efficacy to academic anxiety.
Bandura [2] stated that self-efficacy is a person's belief in his or her ability to do a form of control over his or her own functions and any events in an environment. Bandura also described self-efficacy as the determination of how people feel, think, motivate themselves and behave [3] It was also stated that self-efficacy can be generated and learned through 4 things: mastery experience, social modeling, social persuasion, and physical and emotional conditions. The relation of physical and emotional condition here is then triggering the anxiety. If such anxiety occurs in the academic world, it goes to academic anxiety then.

This is also supported by the results of previous studies showing both the different levels of academic anxiety experienced by the students in UNY in each class and faculty and other aspects including the uncertain feeling of students about their ability to complete assignments from lecturers. Meanwhile, the result of academic anxiety coming out is being anxious if they will submit the assignments from lecturers, the fear of not being able to complete studies on time, and the demands of parents viewed as a burden for the students. It has also been found that there have been a number of differences in the level of academic anxiety experienced by sex, distance traveled to campus, abilities to be mastered in each faculty.

Ottens [4] defined anxiety as the disruption of thought patterns and physical responses as well as the behavior of individual anxiety particularly on academic assignments given. Purwanti, et al. [5] meanwhile stated that academic anxiety is the encouragement of thoughts and feelings among students in the form of fear of incoming danger without any specific reason making the patterns of thought and physical response and behavior disrupted. Both opinions indicate that academic anxiety is a disturbed pattern of thought and physical response and behavior in the academic field.

This study in turn attempted to further and deeply examine the contribution of academic self-efficacy to the academic anxiety of students in UNY. The results were analyzed based on both sex and exact and non-exact faculties.

\section{METHOD}

This correlational study used a descriptivequantitative approach in which the subject of this study was conducted by using random sampling. The population of this study was all students of UNY from 7 (seven) faculties 
and 1 postgraduate program based on the class started from the class of 2016 to 2018 .

The sampling technique used krejcie tables with efficacy level of $90 \%$. Of the total population of 25,904 students using krejcie tables with the efficacy level of $90 \%$, it obtained a sample of 377 students from seven faculties and one graduate program at UNY. The technique of data collection was conducted by distributing the questionnaires about academic self-efficacy and academic anxiety to UNY students.

\section{RESULT AND DISCUSSION}

Result

1. The Results of Correlation Test

Table 1. The Results of Correlation Test

\begin{tabular}{|ll|r|r|}
\hline \multicolumn{3}{|c|}{ Correlations } \\
\hline \multirow{3}{*}{ Keyakinan Diri } & Keyakinan Diri & Kecemasan \\
& Pearson Correlation & 1 & $-647^{-*}$ \\
& Sig. (2-tailed) & & .000 \\
& $\mathrm{~N}$ & 384 & 384 \\
& Pearson Correlation & $-647^{-*}$ & 1 \\
Kecemasan & .000 & \\
& Sig. (2-tailed) & 384 & 384 \\
\cline { 2 - 3 } & $\mathrm{N}$ &
\end{tabular}

The results of the test output of Pearson Correlation model correlation showed a value of $0,000<0.05$ indicating that the variable of academic self-efficacy had a significant correlation with the variable of academic anxiety. The results of the Pearson Correlation model test also showed a correlation value of 0.647 ; thus, the level of correlation strength between the variable of academic self-efficacy and the variable of academic anxiety was strong. The correlation coefficient showed that the value of -0.664 was negative so that the direction of the two variables was opposite, i.e. the higher the academic self-belief, the lower the academic anxiety.

\section{The Results of the Simple Linear Regression Analysis}

The results of the test of simple linear regression analysis is presented as follows:

Table 2. The results of the Simple Linear Regression Analysis Test

\begin{tabular}{|l|c|c|l|}
\hline Model & $\begin{array}{c}\text { Variables } \\
\text { Entered }\end{array}$ & $\begin{array}{c}\text { Variables } \\
\text { Removed }\end{array}$ & Method \\
\hline 1 & KeyakinanAkd & & Enter \\
\hline
\end{tabular}

b. All requested variables entered.

\begin{tabular}{|c|c|c|c|c|}
\hline \multicolumn{5}{|c|}{ Model Summary } \\
\hline Model & $\overline{\mathrm{R}}$ & R Square & $\begin{array}{l}\text { Adjusted R } \\
\text { Square }\end{array}$ & $\begin{array}{l}\text { Std. Error of the } \\
\text { Estimate }\end{array}$ \\
\hline 1 & $647^{\mathrm{s}}$ & .281 & .008 & 13.43911 \\
\hline
\end{tabular}

The results of simple regression analysis showed the Rsquare of 0.281 or $28.1 \%$ indicating that the regression model can explain or illustrate the effect of academic selfefficacy on the decrease in academic anxiety by $28.1 \%$. While $71.9 \%$ was determined by other factors or other independent variables not used in this study.
3. The Results of the Correlation Test and the Analysis of Simple Regression Analysis By Exact and Non-Exact Study

Table 3. the Correlation Test and the Analysis of Simple Regression Analysis By Exact and Non-Exact Study

\begin{tabular}{|c|c|c|c|c|}
\hline & Exacta & $\begin{array}{c}\text { Descriptio } \\
n\end{array}$ & Non-Exacta & $\begin{array}{c}\text { Descripti } \\
\text { on }\end{array}$ \\
\hline $\begin{array}{c}\text { Normality } \\
\text { Test }\end{array}$ & $0,395>0,05$ & Normal & $0,465>0,05$ & Normal \\
\hline Linear Test & $0,148>0,05$ & Linear & $0,503>0,05$ & Linear \\
\hline $\begin{array}{c}\text { Sig. of } \\
\text { Level } \\
\text { Correlatio } \\
n\end{array}$ & $0,00<0,05$ & Significant & $0,00<0,05$ & $\begin{array}{c}\text { Significan } \\
\mathrm{t}\end{array}$ \\
\hline \multirow[t]{2}{*}{$\begin{array}{l}\text { Direction } \\
\text { Correlatio } \\
\mathrm{n}\end{array}$} & 0,463 & Sufficient & 0,544 & Strong \\
\hline & Negative (-) & $\begin{array}{c}X \text { was } \\
\text { high, } Y \text { was } \\
\text { low. } \\
X \text { was low. } \\
Y \text { was high }\end{array}$ & Negative (-) & $\begin{array}{c}\text { X was } \\
\text { high. Y } \\
\text { was low. } \\
\text { X was } \\
\text { low. Y } \\
\text { was high }\end{array}$ \\
\hline $\begin{array}{c}\text { Contributi } \\
\text { on of } \\
X \text { to } Y\end{array}$ & $21,4 \%$ & $\begin{array}{l}79,6 \% \text { was } \\
\text { determine } \\
\text { d by other } \\
\text { factors }\end{array}$ & $29,6 \%$ & $\begin{array}{c}\text { 70,4\% } \\
\text { was } \\
\text { determin } \\
\text { ed by } \\
\text { other } \\
\text { factors }\end{array}$ \\
\hline
\end{tabular}

The results of the Pearson Correlation model test in the exact study showed a correlation value of 0.463 indicting that the level of correlation strength between the variable of academic self-efficacy and variable of academic anxiety was sufficient. The non-exact study meanwhile showed a correlation value of 0.544 showing that the level of the correlation strength between the variable of academic self-efficacy and variable of academic anxiety was strong.

Furthermore, the results of a simple regression analysis among the students in the exact science showed an R-square of 0.214 or $21.4 \%$ indicating the ability of the regression model to explain or illustrate the effect of academic self-efficacy on the decrease in academic anxiety by $21.4 \%$; while $79.6 \%$ was determined by other factors (independent variables) not used in this study.

The results of a simple regression analysis among the students in non-exact science showed an R-square of 0.296 or $29.6 \%$ explaining that the regression model can explain or illustrate the effect of academic self-efficacy on the decrease in academic anxiety by $29.6 \%$; while $70.4 \%$ was determined by other factors (independent variables) not used in this study.

4. The results of Correlation Test and Simple Linear Regression Analysis by Sex

Table 4. The Correlation Test By Sex

\begin{tabular}{l|llll}
\hline & Male & Description & Female & Description \\
\hline Normality & $0,694>$ & Normal & $0,737>$ & Normal \\
Test & 0,05 & & 0,05 & \\
Linear Test & $0,280>$ & Linear & $0,261>$ & Linear \\
& 0,05 & & 0,05 & \\
Sig. Level & $0,001<$ & Significant & $0,002<$ & Significant \\
\hline
\end{tabular}




\begin{tabular}{|c|c|c|c|c|}
\hline \multirow{3}{*}{$\begin{array}{l}\text { Correlation } \\
\text { Direction } \\
\text { Correlation }\end{array}$} & 0,05 & & 0,05 & \\
\hline & 0,246 & Weak & 0,512 & Strong \\
\hline & $\begin{array}{l}\text { Negative } \\
(-)\end{array}$ & $\begin{array}{l}X \text { was high. } \\
Y \text { was low, } \\
X \text { was low, } \\
Y \text { was high }\end{array}$ & $\begin{array}{l}\text { Negative } \\
(-)\end{array}$ & $\begin{array}{l}X \text { was high, } \\
Y \text { was low, } \\
X \text { was low, } \\
Y \text { was high }\end{array}$ \\
\hline $\begin{array}{l}\text { Contribution } \\
\text { of } X \text { to } Y\end{array}$ & $11,4 \%$ & $\begin{array}{l}88,6 \% \text { was } \\
\text { determined } \\
\text { by other } \\
\text { factors }\end{array}$ & $28,6 \%$ & $\begin{array}{l}71,4 \% \text { was } \\
\text { determined } \\
\text { by other } \\
\text { factors }\end{array}$ \\
\hline
\end{tabular}

The results of the Pearson Correlation model test on male students showed a correlation value of 0.246 . This then showed that the level of correlation strength between the variable of academic self-efficacy and variable of academic anxiety was weak. The female students in contrast showed a correlation value of 0.512 representing the strong level of correlation strength between the variable of academic self-efficacy and variable of academic anxiety.

Furthermore, the results of simple linear regression test in male students showed an R-square of 0.114 or $11.4 \%$ showing that the ability of regression model to explain or illustrate the effect of academic self-efficacy on the decrease in academic anxiety by $11.4 \%$. Meanwhile, $88.6 \%$ was determined by other independent variables not used in this study.

The results of a simple linear regression test on female students showed an R-square of 0.286 or $28.6 \%$ and this showed that the regression model could explain or illustrate the effect of academic self-efficacy on the decrease in academic anxiety by $28.6 \%$; while, $71.4 \%$ was influenced by other factors or independent variables not used in this study.

\section{The Results of the Correlation Test and the Simple Regression Analysis by Class}

The results of the correlation test and the simple regression analysis by class of 2016, 2017, and 2018 are presented as follows.

Table 5. Correlation Test by Year of Class

\begin{tabular}{l|llllll}
\hline & 2016 & description & 2017 & description & 2018 & description \\
\hline Nor & 0,93 & Normal & 0,17 & Normal & 0,86 & Normal \\
malit & $9>$ & & $6>$ & & $7>$ & \\
y & 0,05 & & 0,05 & & 0,05 & \\
Test & & & & & & \\
Line & 0,86 & Linear & 0,08 & Linear & 0,11 & Linear \\
ar & $6>$ & & $2>$ & & $7>$ & \\
test & 0,05 & & 0,05 & & 0,05 & \\
Signi & 0,00 & Significan & 0,00 & Significant & 0,00 & Significant \\
fican & $1<$ & t & $3<$ & & $3<$ & \\
ce & 0,05 & & 0,05 & & 0,05 & \\
Sig. & 0,47 & Sufficient & 0,45 & Sufficient & 0,31 & Sufficient \\
Corr & 7 & & 5 & & 8 & \\
elati & & & & & & \\
on & & & & & & \\
Corr & Neg & X was & Neg & X was high, & Neg & X was high, \\
elati & ative & high, Y & ative & Y was low, & ative & Y was low, \\
on & $(-)$ & was low. & $(-)$ & X was low, & $(-)$ & X was low, \\
Dire & & X was & & Y was high & & Y was high \\
ction & & low, Y & & & & \\
& & was high & & & & \\
\hline
\end{tabular}

\begin{tabular}{|c|c|c|c|c|c|c|}
\hline $\begin{array}{l}\text { Cont } \\
\text { ribut } \\
\text { ion } \\
\text { of } \\
X \text { to } \\
Y\end{array}$ & $\begin{array}{l}27,1 \\
\%\end{array}$ & $\begin{array}{l}72,9 \% \\
\text { determin } \\
\text { ed by } \\
\text { other } \\
\text { factors }\end{array}$ & $\begin{array}{l}21,7 \\
\%\end{array}$ & $\begin{array}{l}78,3 \% \\
\text { determined } \\
\text { by other } \\
\text { factors }\end{array}$ & $\begin{array}{l}18,4 \\
\%\end{array}$ & $\begin{array}{l}81,6 \% \\
\text { determined } \\
\text { by other } \\
\text { factors }\end{array}$ \\
\hline
\end{tabular}

The results of the Pearson Correlation model test for the students of 2016-class and 2017 class showed a correlation value of 0.477 and 0.455 respectively. Thus, it can be stated that the level of correlation strength between the variable of academic self-efficacy and variable of academic anxiety was sufficient in both classes. Whereas the 2018 students got a correlation value of 0.318 showing the weak level of correlation strength between the variable of academic self-efficacy and variable of academic anxiety.

Simple regression analysis results showed $27.1 \%$, in the class of 2016, 21.7 in the class of 2017 and $18.4 \%$.in the class of 2018. The remains were determined were determined by other factors (independent variables) that were not used in this study.

\section{Discussion}

The results of this study indicated that self-efficacy (Academic self-efficacy) for UNY students had a significant negative correlation to academic anxiety in which the higher the Academic self-efficacy, the lower the academic anxiety. This is in line with the concept of social cognitive theory, suggesting that low self-efficacy will lead to the increasing anxiety and avoidance behavior. Individuals will avoid any activities that can aggravate the situation and this is not caused by threats but the feeling that they do not have an ability to manage any risky aspects [6].

Another study by Jex et al. [7] conducted on people facing an excessive workload showed a negative correlation between self-efficacy and stress levels. Individuals with high Academic self-efficacy have a low stress level. When people with excessive workloads have high academic selfefficacy, they have a tendency to avoid stress. Excessive academic anxiety can have an impact on the effectiveness of a student's daily activities.

This study also found that academic self-efficacy had an impact on reducing academic anxiety by $28.1 \%$ while $71.9 \%$ was influenced by factors or other independent variables not used in this study. This opinion is also supported by McDougall and Kang's [8] research revealing a negative correlation between self-efficacy and anxiety.

\section{CONCLUSION}

The results of the Pearson Correlation model analysis test showed a correlation value of -0.674 with the opposing direction of the two variables, i.e. the higher the academic self-efficacy the lower the academic anxiety of students in UNY. The results of simple regression analysis showed an R-square of 0.281 or $28.1 \%$ and this showed an ability of the regression model to explain or illustrate the effect of academic self-efficacy on the decrease in academic anxiety by $28.1 \%$. While, $71.9 \%$ has been determined by other factors (independent variables) that were not used in this study. 


\section{REFERENCES}

[1] Arnaiz, Patricia and Pérez-Luzardo, Jessica (2016) A Study on The Correlation Between Anxiety and Academic Self-Concept in Interpreter Trainees. Círculo de lingüística aplicada a la comunicación Journal, Vol 67, 57-88.

[2] Feist, Jess dan Gregory J. Feist. 2010. Teori Kepribadian. Jakarta: Selemba Humanika.

[3] Bandura, A. (1994). Self Efficacy. In V. S. Ramachaudran (Ed.), Encyclopedia of human behavior (Vol. 4, 77-81). New York: Academic Press

[4] Ottens, A. J. (1991). Coping with Academic Anxiety. New York: The Rosen Publishing Group.
[5] Purwanti, Isti Yuni et al. 2017. Pengembangan Model Keterampilan Konseling Individual berbasis SEFT untuk Mengurangi Kecemasan Akademik Siswa SMP di DIY. Research Report. Not published yet. Alwisol. 2009. Psikologi Kepribadian Revised Edition. Malang: UMM Press.

[6] Bandura, A. (1997). Self-Efficacy the Exercise of Control. New York: W.H. Freeman and Company.

[7] Jex, S. M., Bliese, P. D., Buzzell, S., \& Primeau, J. (2001). The Impact of Self- Efficacy on Stressor-Strain Relations: Coping Style as Explanatory Mechanism. Journal of Applied Psychology, 86(3), 401-409.

[8] McDougall, G. J., \& Kang, J. (2003). Memory Self-Efficacy and Memory Performance i n $\mathrm{O} 1 \mathrm{~d}$ e r $\mathrm{M}$ a $1 \mathrm{e} \mathrm{s}$. International Journal of Men's Health, 2(2), 131-147. 